\title{
HABITS IN LIFE - FROM BHAGAVAD GITA
}

\section{Dr. DANTU MURALIKRISHNA}

Senior General Manager, Lupin Limited, Mandideep, Dist. Raisen, Madhya Pradesh, India

\begin{abstract}
Our habits, are important to have better health, peace and ultimately lead to happiness all around in our lives. These are described in the scripture, Bhagavadgita, which make us to be happy and healthy and to elevate our lives. One can understand about the habits for better life and also can understand the habits; those can lead towards the path of destruction from the scripture of Bhagavad-Gita. Explored these aspects from "Bhagavad-Gita", and summarized herein for the benefit of all, describing what should be followed and what should not be. In brief, the habits described are: 1) Rules \& Regulations 2) Food \& Sleeping 3) Properties 4) Work \& Actions, 5) Language of Speech, 6) Yoga \& Meditation, 7) Self-Control 8) Equality, 9) Purpose \& Goal.
\end{abstract}

KEYWORDS: Bhagavadgita \& Habits

Received: Aug 01, 2019; Accepted: Aug 23, 2019; Publibshed: Sep 12, 2019; Paper Id.: IJESROCT20191

\section{INTRODUCTION}

We all would like to live happily with peace and progress all around. It is natural that we do many such activities for self-happiness and for happiness of our beloved as well. However, we are not very clear what brings us the happiness and through what, we can attain. Many know that, our habits, which we follow are responsible for our happiness all the way. Habits mean not that just what we do daily. They are to be inbuilt in our personality and inbuilt in our character, which can be the factors for happiness or worry for us and/or for others. Many aspects are described 5000 years back in "Shrimad Bhagavad Gita", and practicing of those sutras provide us the happiness and peace in life. Lord Krishna explained to Arjuna, when Arjuna was not happy in the battle field as he was to fight with his own people. The happiness or unhappiness is more related to mental stability and desires of individuals and the result of the events and worries in life at different contexts. Main factors for unhappiness, are because of the habits and practices, which we do ignore to follow in life. Most important is the balance in our life that affects and disturbs us a lot. Few of the aspects described, in Bhagavad Gita are captured and discussed herein for the benefit of the readers.

\section{RULES \& REGULATIONS}

There is lot of literature available in India, and one should read and study or need to listen from the scholars to absorb and act in a right way. Many times, because of the lack of subject knowledge, we get confused and select the wrong path and at the end, we upset with unexpected results. Hence, referring the Shastras and standard sutras there in, is helpful to pursue the things rightly. Or better to follow, what scholars told. Many do not like to follow these laid down sutras and follow as per their wish and end up with nowhere, and that become the factor for worry. It means, important is the education and study of literature and standard books to absorb and follow in life with discipline. 
yahshastravidhimutrusjya varthathe kamakaratah

na sa sidhimavapnothi na sukham na paramgathim

thasmatchashtram pramanamthe karya karyavyvasthithou

jnatva shastravidhanoktham karma karthumiharhasi

In Bhagavad Gita, in verses $16.23 \& 24$, it is told that, "who discards the injunctions of scriptures, who acts in an arbitrary way as per his own will- such a person will neither attain the stage of perfection nor experience happiness, nor achieve the ultimate goal of life or destination. Therefore, to understand, what is duty and what is not, the scriptures are the guidelines. Knowing such rules and regulations from the scriptures, one should perform duty as per those guidelines".

\section{FOOD \& SLEEPING}

There is lot described in Bhagavad Gita about the kind of food to be taken and its impact on health and character of the person. It is well described about the food and sleeping habits to maintain the health and to improve our behavioral and character aspects. About the food and sleeping habits, very well described in below verses of Bhagavad Gita.

natyasnathasthu yogosthi na chikanthamanasnathah

na chathiswapnasheelsya jagratho niva charjuna

yukthaharaviharsya yukthacheshtasya karmasu

yukthaswapnavabodhasya yogo bhavathi duhkhahaa

To focus on any task, with full concentration, there is sufficient amount of intake and sleep are required and that provides energy in our efforts. There is no possibility of becoming Yogi, who eats lot or who eats too little and who sleeps too much or who does not sleep enough. Balanced eating, balanced recreation, balanced working, balanced sleeping and waking, along with practice of yoga leads to a misery-free life.

\footnotetext{
Aayuhsathvabalaarogyasukhapreethivivardhanaah

rasyaah snigdhah sthirahridya aaharaah svathvikapriyah

katvamlalavanathyushnatheekshlaroookshavidahinah

aaharaa raajasasyeshta duhkhashokamayapradah

yaathayaama gatharasam puthi paryushitha cha yath

uchishthamapi chamedhyam bhojanam thamasapriyam
}

The above verses explain that, healthy foods are those, which are juicy, mild and wholesome, which are beneficial. Eating such foods prolongs life span, purifies one, increases vitality, immunizes from diseases, increases happiness levels and improves appetite. Foods those are extreme in bitterness, sourness, saltness, hotness, dryness and fieriness -called as passion foods. Consuming such foods causes pain, misery and unhealthiness. Foods, those are stale, foul smelling, tasteless, putrid, remnants of others, unfit to be offered. Therefore, the quality of food, is important as it matters on our health. 


\section{PROPERTIES}

In true meaning, for a person, the asset is his own character and not just having the wealth or possessions. It is behavior and the signatures of a person, recognized by others. People are usually of different in nature but only few gets the name and fame and that is only possible by way of their behavior and character. The qualities of a person, needed, can be described on many fronts but few are considered herein for discussion. Both the positive factors and the negative factors are well defined in bellow verses of Bhagavad Gita.

Thejakshamadhrithihshouchamadrohonathimanitha

bhavanthi sampadam diveemabhijathasya bharatha

dambho darpobhimanashcha krodhahparushyamevacha

ajnanam chabhijathasya partha sampadamasureem

anekachithavibhranthaa mohajalasamavruthah

prasakthahkamabhogeshu pathanthi narakeshuchou

Sublimity, forgiveness, fortitude, purity, no enemy to anyone, and absence of self-esteem- these are the marks of the person, who born with the divine endowments. Pride, arrogance, self-respect, anger, harshness, and ignorance - these are the marks of the person, who born with demoniac properties. Clouded by unlimited anxieties and strongly influenced by super complex network of illusions, such people become addicted to selfish desires and drop into hellish existence.

devadvijaguruprajnapujanam shochamarjavam

brahmacharyamahimsa cha shareeram thapa uchathe

Worship of Gods, brahmanas, masters, elders and having cleanliness, purity, simplicity, celibacy, non-violence these are all called penance of the body. These are the qualities to be brought in practice for betterment with peace and happiness.

These properties a person decide their quality of actions and speech and attitude on which the personality of that person can be judged.

\section{WORK \& ACTIONS}

For everyone, work is needed to earn and importantly to maintain our body. Work itself is an exercise and provides required energy to the body and a lazy person lose motivation and spirit of readiness for challenges and cannot lead the life happily. At the same time, it is important to know the quality of work to be pursued and the time of acting on the same. Because, if the work is not time bound, and the action is not in time, there is no merit of such activity and of such candidature. This is the case for Arjuna in Mahabharata. When the battle was just about to start, Arjuna lost his spirit and changed his mind to drop the fight against the opponents. The action should be appropriate and at the right time. Lord Krishna explained in Verse, how Arjuna can lose his name and fame, if he drops the action to fight at that time, which was decided by all in advance. When time demands you to work, the action is needed from you. For every right action, there is a right time to perform. Work is important for the survival of self and the dependents. The person is not useful for self and for others, if does not do any work. 
kuthastva kasmalamidam vishame samupasthitham

anaaryajushthamaswargyamkeerthikaramarjuna

niyatham kuru karmathvam karma jyaayohyakarmanaha

shareerayatrapi cha the na prasidhyedakarmanaha

When Arjuna dropped to fight against evil in last minute, Lord Krishna told, "how you got this infatuation at this hour of crisis. It is not the right act of superiors to exhibit. Neither it will bring you any fame nor will lead you to heaven". Lord Krishna explained to Arjuna that "better to perform the prescribed duty than to remain without doing anything. Because action is superior to inaction. You cannot even maintain your own body without work. Further, the quality of superior actions to practice in life are described in the below verse 18.5.

yajnadanathapahkarma na tyajyam karyameva thath

yajnodanam thapashchiva pavanani maneeshinam

Acts of sacrifices, charity and penance are not worth giving up. They must be performed. All these purify even the great wise men. Great people know that these are important to perform as they enrich their character with such actions.

\section{LANGUAGE OF SPEECH}

Quality of speech is important for any individual as that matters to gain or lose the personality. What, one should keep in mind and make as practice in life while speaking to others is well described in the verse in Bhagavad Gita. Our language of speech shows our candidature, character, attitude and respect towards others. Our speech speaks our maturity and our knowledge. The quality of speech needed is well described in the verse 17.15 of Bhagavad Gita. It is essential to maintain the own words and promises made to others. That is what the Kaoravas did not maintain their promises of returning the kingdom to Pandavas and is the reason for the war and destruction in Mahabharata. In our lives, we usually see that many make promises for their benefit and they don't follow their own words of promise. They are the people, who have no character and no purity in their words and behavior. The speech should be pleasing and helpful to others. Pleasing others does not mean, telling untrue words. The speech should be with truth and at the same time pleasing and beneficial to others. Knowledge is important and for that as said in the very beginning (16.23 \& 24), one should study the Shastras and the sutras therein, to follow in right path.

anudvegakaram vakyam sathyam priyahitham cha yath

swadhyayaabhyasanam chiva vangmayam thapa uchyathe

Speech, which cause no annoyance to others, and are truthful, pleasing, beneficial as well as the study of the Vedas and other Shastras (scriptures) and practice of the chanting of spiritual acts - this is called as penance of speech. It means, needed great practice and make it a habit in life on these qualities for betterment.

\section{YOGA \& MEDITATION}

Yoga is described in Bhagavad Gita beyond performing meditation and physical postures. In Bhagavad Gita, it is explained through various procedures including the significance of spirituality for eternal peace. As per Bhagavad Gita, Yoga is to purify our actions, Yoga is to control the mind and senses and Yoga is to link oneself to Supreme with devotion. Yoga is the path of selfless actions without expecting the consequences or end results. The definition of Yoga is not restricted to 
the bodily postures but rather, it encompassed a wide range of ways to connect with one's potential for many benefits. Yoga cannot be practiced without renouncing selfish motive. Yoga, on practicing, it helps to have peace, happiness and enlightenment in life. There are many health benefits as described by many by performing Yoga in our lives. To focus on work, there is need of self-control, without deviation in our efforts and without side tracks by other attractions. Yoga can be defined as not being attached to one's actions, senses and having no selfish motives but only for the purification of self. For the performer of Yoga, the surroundings and the stability of mind are important. Also, the concentration of mind towards the destiny without any diversion and desire is essential. It is possible for the person- who- lives alone in a secluded place and constantly engage his mind in meditation. One should hold the body, head and neck straight and steady, remaining firm and fixing the gaze on the tip of his nose, without looking in other directions (6.10 \& 6.13). Yoga is important for our physical health and for our mental health. Also, it leads towards spirituality and improves the quality of our actions and life. For all this, a controlled mind is needed and that is only possible through practice as described. This is the way of meditation to attain the peace, happiness and enlightenment in life.

yogee yunjeetha sathathamathmanam rahasthithaha

yekakee yathchithathma nirasheeraparigrahaha

samam kayashirogreevam dharayannachalam sthiraha

samprekshya naasikagra, swam dishaschanavalokayan

As described in the verse (17.16), one who follows meditation, can be free from many health-related issues as he/she acquire mental stability and health through mediation. Cheerfulness of mind, placidity, habit of contemplation on God, control of the mind, and purity of inner feelings - all this called as austerity of the mind.

manahprasadah soumyathvam mounamatmavinigrahaha

bhavasamshudhirithythathpo manasamruchyathe

\section{SELF-CONTROL}

In Bhagavad Gita, Srikrishna described about the senses of the body and their characteristics. The habit of controlling them is necessary, and that is to be practiced for greater happiness.

yathatho hyapi kountheya purushasya vipaschithaha

indriyani pramatheeni haranthi prasabham manaha

ye hi samsparsaja bhogaa duhkhayonaya yevathe

aadhyanthavanthaha kountheya na theshu ramathe budhaha

The senses are so strong and impetuous that they forcibly carry away the mind, even of a wise man, who is practicing of controlling them. The unsteady fickle mind tends to wander away. Every time the mind wanders away, the controller pulls it back to remain under the control of the self. The pleasures which are born of sense-contacts are undoubtedly a source of suffering only. They come and go and not permanent. Therefore, the wise man does not delight in them. In Bhagavad Gita, it is told that, it is difficult but possible, to control and conquer on our senses by practice and detachment. All because of the attractions all around and because of wavering mind. We need to accomplish the work with the help of senses, which are under control and is possible only through practice and with stable mind. 
vihaya kamanyaha sarvanpumascharathi nihspruhaha

nirmamo nirahankaraha sa shanthimadhigachhathi

Abandoning all desires for sense indulgence, a person, who is free from desires, without a sense of proprietorship and devoid of egotism, such a person attains lasting peace. Peace and happiness are most important for all and possible by way their actions and by way of their control on their senses to lead on right path for positive results.

\section{EQUALITY}

These days, many favour and show partiality towards their own people and towards his beloved ones and uses their capacity of position or power for their benefit and provide the comfort and everything for them. Because of this, the right and eligible candidates are affected through they are well qualified and talented. On equality, how a person should behave, is well described in Bhagavad Gita, describing as, one should maintain equality in all the living beings. A person, who looks upon -well-wishers, neutrals, mediators, friends and foes, relatives and inimical, the pious and sinners -with equanimity, that person is considered supreme of all. The true yogi, sees all beings even and indeed beholds the selfexisting in all beings and all beings in the self. The practice of impartiality and to act with equal attitude towards all, brings happiness for self and in all.

Suhunmitraryudaseenamadyasthadveshyabandhushu

sadhushvapi cha papeshu samabudhirvishishyathe

sarvabhuthasthamathmanam sarvabhuthani chathmani

eekshatheyogayukthathmasarvatrasamadarsanaha

\section{PURPOSE AND GOAL}

Whatever, the activities we do, there is a purpose and the goal but ultimately, we all expect the happiness with the end results of our work. However, self-realization and acceptance of the results are important to have the peace and happiness. The qualities needed to be happy are described in the above verses. In brief, a person who does the following things attain self-realization and happiness: using his purified intelligence, controls the mind with determination, gives up selfish enjoyment, frees himself from attachment and aversion, lives in a secluded place, eats minimal, controls the faculties of the body, mind and speech, always absorbed in higher consciousness, is free from false ego, false strength, false pride, false proprietorship, lust and anger and is peaceful.

The factors discussed above, are for being happy. However, achieving the state of mind, that not disturbed by any happiness or by any worry, is the ultimate thing and that can be possible for a rare person only and that person is called as "Sage of steady mind". As per the verse (2.56) of Bhagavad Gita,

duhkheshvanudvignamanaha sukheshu vigathaspruhaha veetharagabhayakrodhaha sthithadheermuniruchyathe

yasmannodvijathe loko lokannodvijathe cha yaha

harshamarshabhayodvegirmuktho yah sa cha me priyaha 
One, who is not disturbed in mind with amid of sorrows or elevated with excitement of happiness and who is free from attachment, fear and anger - is called as a "Sage of steady mind". Also explained by Lord Krishna, the qualities of the person to whom he likes. "Krishna told that, "By whom, no one is put into difficulty and who himself not disturbed by any one and who is free from happiness, envy, fear and anxiety-he is very dear to me". Therefore, the actions are important to lead the life, if we want to attain the ultimate goal, which always differs from each other and that depends on individual characteristic properties and practices.

\section{CONCLUSIONS}

It is very important-to follow the guidelines as described in shastras, to follow the food and sleeping habits as explained, to follow good character, to focus on work with quality actions, to practice good speech, to practice yoga and meditation with self-controls, maintaining equality among all and with purpose and goal of actions to have better health, peace and happiness in life. The do's and don'ts are explained for self-happiness and for the happiness of others to have the peace all around, which is possible by self-development and by our actions through practice on these aspects.

\section{REFERENCES}

1. Swagatika Nanda, Management Lessons from Bhagavad Gita; International Journal of Applied Research (IJAR) 2016, 2(4): 650-652

2. Dr. MedaSrinivasa Rao, Bhagavad Gita a key source for management thoughts - An analysis; Acme Intellects International Journal of Research in Management; Vol 6, No 6, Apr 2014

3. Usha Sundari and Karanam N Rao, Leadership Lessons from Bhagavad Gita; DEV SANSKRITI: Interdisciplinary Journal (2014), 03, 19-24

4. Arun Korath and Sangheethaa S, Happiness Management Through Bhagavad Gita; International Journal of Current Advanced Research; Vol 4, Issue 2, pp 22-24, 2015

5. Kibui, A. W. (2014). Language policy in Kenya and the New Constitution for Vision 2030. International Journal of Educational Science and Research, 4(5), 89-98.

6. “Shrimad Bhagavad Gita (Telugu), Shri Jayadayal Govindaka, and translation by Dr. M. KrishnamaCharyulu \& Dr. Goli Venkata Ramayya, 2011

7. Dr. Omprakash M. Ashtankar, KITS, Ramtek, India; Mind Management : Lessons from Bhagavad Gita; International Journal of Advanced Research in Computer Science and Management Studies; Vol 4, Issue 3, March 2016

8. Kumar Alok, Leadership : The Bhagavad-Gita Paradigm; Bhavan's International Journal of Business, Viol 5, 1 (2011)

9. Patra, B. (2013). Importance of Language Laboratory in Teaching Grammar. International Journal of Research in Humanities, Arts and Literature (IJRHAL), 1(2), 9-16.

10. Prof. Prem Shankar Srivasthava, Ensuring Personality Development through Bhagavad-Gita's teachings; International Journal of research in Social Sciences; Vol 6, Issue 11, November 2011

11. Prof. Biswajit Satpathy, The Knowledge of "Self" from the Bhagavad Gita and its Significance for Human Capital Development; Asian Social Science, Vol 4, No. 10 October 2008

12. Sujit Kumar Acharya, Lessons in Management from Bhagavad Gita; International Journal of Research and Development - A Management Review (IJRDMR); Vol 4, Issue 2, 2015. 
13. Devi, K. L. Figurative Language and Imagery in the Short Stories of John Updike.

14. “www.google.com” for "Shrimad Bhagavad Gita”

\section{AUTHOR PROFILE}

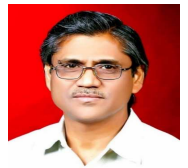

Dr. Dantu Muralikrishna (MSc, Ph.D), Senior General Manager, Lupin Limited. I have 35 years of industrial experience in pharma companies. I have number of papers and patents for my various research developments. Though I am a scientist, recently I have made an Audio album and also published Book on Bhagavad Gita with selection of 108 shlokas to be useful for all in both Hindi \& Telugu languages with the title of "SambhavamiYugeYuge". 